\title{
PENGARUH MODEL PEMBELAJARAN KOOPERATIF TIPE STUDENT TEAMS ACHIEVEMENT DIVISIONS (STAD) TERHADAP KEMAMPUAN PEMAHAMAN KONSEP MATEMATIS
}

\section{THE INFLUENCE OF THE STUDENT TEAMS ACHIEVEMENT DIVISIONS (STAD) COOPERATIVE LEARNING MODEL ON UNDERSTANDING ABILITIES MATHEMATIC CONCEPTS}

\author{
LILY ROHANITA HASIBUAN ${ }^{1}$, EVA JULYANTII ${ }^{2}$ INDAH FITRIA RAHMA ${ }^{3}$, MARSIANI ${ }^{4}$ \\ 1,2,3,4 Program Studi Pendidikan Matematika, FKIP Universitas Labuhanbatu \\ Jalan Sisingamangaraja No. 126A, KM. 3,5 Aek Tapa Rantauprapat, \\ email:1'Irohanita30@gmail.com, ${ }^{2}$ evajulianti.26@gmail.com, ${ }^{3}$ indahfitria286@gmail.com \\ ${ }^{4}$ marsiani.21@gmail.com
}

\begin{abstract}
Abstrak
Tujuan penelitian ini adalah untuk mengetahui pengaruh model pembelajaran kooperatif Student Teams Achievement Divisions (STAD) terhadap kemampuan pemahaman konsep matematika siswa. Penelitian dilaksanakan di SMA Negeri 2 Torgamba. Jenis penelitian kuantitatif dengan metode kuasi eksperimen dan desain penelitian One-Group Pretest-Posttest Design. Sampel dalam penelitian ini adalah siswa kelas $\mathrm{X}^{2}$ yang berjumlah 40 siswa dengan menggunakan instrumen tes tipe uraian sebanyak 5 soal. Data diperoleh dari hasil tes yang diberikan kepada siswa berupa soal pretest yang diberikan sebelum proses pembelajaran dan posttest yang diberikan diakhir proses pembelajaran. Nilai siswa sebelum diberi perlakuan dengan nilai tertinggi 47, nilai terendah 19 dengan rataan 35,125 dan standar deviasinya 5,69. Sedangkan setelah diberi perlakuan menggunakan model pembelajaran problem posing terdapat peningkatan yaitu nilai tertinggi 48, nilai terendah 21 dengan rataan 37,075 dan standar deviasinya 6,05 Secara umum siswa kelas $X^{2}$ setelah diberi perlakuan mengalami peningkatan. Analisis data menggunakan uji Paired Samples T-Test, berdasarkan analisis data tersebut diperoleh nilai $t_{\text {hitung }}>t_{\text {tabel }}$ yaitu $13,250>2,02$ berarti ada perbedaan yang signifikan dari pengukuran data pretest dan posttest. Maka $\mathrm{H}_{\mathrm{a}}$ diterima dan dapat disimpulkan bahwa terdapat pengaruh model pembelajaran Kooperatif Student Teams Achievement Divisions (STAD) terhadap kemampuan pemahaman konsep matematika siswa pada materi Sistem Persamaan Linear Dua Variabel. Didukung dengan hasil data angket respon siswa terhadap minat belajar dengan model pembelajaran Kooperatif Student Teams Achievement dengan rataan 82 (41\%) dalam katagori sangat setuju. Hal ini menunjukan respon siswa terhadap model pembelajaran Student Teams Achievement Divisions (STAD) tergolong baik terutama pada materi sistem persamaaan linear dua variabel.
\end{abstract}

Kata Kunci : Model Pembelajaran Kooperatif tipe Student Teams Achievement Divisions (STAD), Kemampuan Pemahaman Konsep Matematis

\begin{abstract}
The purpose of this study was to determine the effect of the Student Teams Achievement Divisions (STAD) cooperative learning model on students' ability to understand mathematical concepts. The research was conducted at SMA Negeri 2 Torgamba. This type of research is quantitative with a quasi-experimental method and research design is One-Group Pretest-Posttest Design. The sample in this study was class X2 students, totaling 40 students using a description type test instrument with 5 questions. Data obtained from the results of tests given to students in the form of pretest questions given before the learning process and posttest given at the end of the learning process. The student's score before being treated with the highest score was 47 , the lowest score was 19 with a mean of 35.125 and a standard deviation of 5.69. Meanwhile, after being treated using the problem posing learning model, there was an increase, namely the highest score was 48 , the lowest score was 21 with an average of 37,075 and a standard deviation of 6.05. In general, students of class X2 after being given treatment experienced an increase. Data analysis used the Paired Samples T-Test, based on the analysis of the data, the value of tcount $>$ ttable was $13.250>2.02$, meaning that there was a significant difference between the pretest and posttest data measurements. Then $\mathrm{Ha}$ is accepted and it can be concluded that there is an effect of the Cooperative Student Teams Achievement Divisions (STAD) learning model on the ability to understand students' mathematical concepts in the material for the Two Variable Linear Equation System. Supported by the results of questionnaire data on student responses to interest in learning with the Cooperative Student Teams Achievement learning model with an average of $82(41 \%)$ in the category of strongly agree. This shows that the student's response to the Student Teams Achievement Divisions (STAD) learning model is quite good, especially on the material of a two-variable linear equation system.
\end{abstract}

Keywords: Cooperative Learning Model Type Student Teams Achievement Divisions (STAD), Ability to Understand Mathematical Concepts 


\section{Pendahuluan}

Matematika adalah suatu alat untuk mengembangkan kemampuan berpikir, karena itu matematika sangat diperlukan baik dalam kehidupan sehari-hari, sehingga matematika perlu diberikan pada setiap jenjang pendidikan mulai dari pendidikan usia dini hingga perguruan tinggi. Matematika pada hakekatnya memiliki objek kajian yang abstrak dan sepenuhnya menggunakan pola pikir deduktif. Mata pelajaran matematika berfungsi mengembangkan kemampuan berkomunikasi dengan menggunakan bilangan dan menggunakan ketajaman penalaran untuk menyelesaikan persoalan sehari-hari. Sasaran dari pembelajaran matematika adalah siswa diharapkan lebih memahami keterkaitan antara topik dalam matematika serta manfaat bagi bidang lain. Untuk menguasai materi pelajaran matematika pada tingkat kesukaran yang lebih tinggi diperlukan penguasaan materi tertentu sebagai pengetahuan prasyarat, salah satunya yaitu dengan memiliki pemahaman konsep yang baik sehingga memudahkan siswa dalam menerima materi selanjutnya[1].

Untuk mempelajari matematika hendaknya berprinsip pada: (1) Materi matematika disusun menurut urutan tertentu atau tiap topik matematika berdasarkan subtopik tertentu; (2) Seorang siswa dapat memahami suatu topik matematika jika ia telah memahami subtopik pendukung atau prasyaratnya, (3) Perbedaan kemampuan antarsiswa dalam mempelajari atau memahami suatu topik matematika dan dalam menyelesaikan masalahnya ditentukan oleh perbedaan penguasaan subtopik prasyaratnya; (4) Penguasaan topik baru oleh siswa tergantung pada penguasaan topik sebelumnya[2]. Hal ini berarti bahwa pemahaman suatu konsep matematika sangat diperlukan siswa untuk dapat memahami materi pembelajaran matematika berikutnya dengan baik.

Salah satu upaya yang dapat dilakukan untuk meningkatkan sumber daya manusia adalah peningkatan mutu pendidikan, baik prestasi belajar siswa maupun kemampuan guru dalam melaksanakan proses pembelajaran. Peningkatan mutu pendidikan diarahkan untuk meningkatkan kualitas manusia seutuhnya melalui olah hati, olah rasa, dan ulah raga agar memiliki daya saing dalam menghadapi tantangan global[3]. Untuk pencapaian hasil belajar yang maksimal siswa harus mencapai ketuntasan indikator dari setiap aspek pembelajaran yang diterapkan oleh guru[4].

Berdasarkan hasil observasi yang dilakukan melakukan wawancara terhadap guru mata pelajaran matematika diperoleh informasi bahwa terdapat hambatan dalam pembelajaran matematika yaitu kurangnya pemahaman siswa dalam menguasai materi yang diajarkan, apalagi dilihat dari bisa motivasi belajar mereka rendah. Selain itu, model pembelajaran yang sering digunakan oleh guru adalah model pembelajaran konvensional, yaitu berupa ceramah dan tanya jawab.

Pada pembelajaran matematika pemahaman konsep sangatlah penting. Oleh karena itu, diperlukan model pembelajaran yang sesuai dengan kondisi ini. Pembelajaran merupakan aktivitas dan proses yang sistematis dan sistemik yang terdiri dari beberapa komponen yaitu: guru, kurikulum, anak didik, fasilitas, dan administrasi. Masing-masing komponen tidak bersifat parsial atau berjalan sendiri-sendiri, tetapi harus berjalan secara teratur, saling bergantung, komplementer dan berkesinambungan. Untuk itu diperlukan rancangan dan pengelolaan belajar yang baik yang dikembangkan dalam rangka mencapai tujuan pembelajaran[5]. Salah satu alternatif model pembelajaran yang digunakan adalah model pembelajaran kooperatif tipe STAD (Student Teams Achievement Division) merupakan model pembelajaran yang melibatkan siswa untuk saling membantu dan mendukung dalam menyelesaikan tugas sehingga mempunyai banyak kesempatan untuk mengolah informasi dan meningkatkan keterampilan berkomunikasi. Model pembelajaran STAD (Student TeamsAchievement Divisions) merupakan salah satu model pembelajaran kooperatif untuk membangun pembelajaran yang aktif[6].

Pembelajaran kooperatif tipe STAD (Student Teams Achievment Division) merupakan salah satu model pembelajaran kooperatif yang lebih membiasakan siswa untuk belajar berkelompok dalam rangka memecahkan masalah atau mengerjakan tugas, di samping itu pembelajaran kooperatif tipe STAD dapat membantu siswa memahami konsep-konsep pelajaran yang sulit serta menumbuhkan kemampuan kerjasama, berpikir kritis, dan mengembangkan sikap sosial siswa. Siswa bekerja sama dalam situasi semangat pembelajaran kooperatif seperti membutuhkan kerjasama untuk mencapai tujuan bersama dan mengkoordinasikan usahanya untuk menyelesaikan tugas[7].

Dalam model pembelajaran kooperatif tipe STAD, siswa dikelompokan dalam suatu kelompok kecil yang heterogen dalam hal kemampuan akademis, jenis kelamin, dan sosial ekonomi. Kesulitan pemahaman materi yang tidak dapat dipecahkan sendiri dapat dipecahkan secara bersama-sama dalam kelompoknya dengan bimbingan guru.

Berdasarkan uraian di atas, peneliti tertarik untuk mengadakan penelitian tentang "Pengaruh Model Pembelajaran Kooperatif Tipe Student Teams-Achievement Divisions (STAD) terhadap Kemampuan Pemahaman Konsep Matematika Siswa kelas X SMA Negeri 2 Torgamba."

\section{Metode Penelitian}

Penelitian ini dilaksanakan di SMA Negeri 2 Torgamba dikecamatan Torgamba kabupaten labuhan batu selatan. Populasi dalam penelitian ini adalah semua kelas X SMA Negeri 2 Torgamba yang terdiri dari empat 
Hal : $20-25$

kelas dengan jumlah siswa 132 siswa. Sampel diambil dari populasi kelas $\mathrm{X}^{2}$ berjumlah sebanyak 40 siswa sebagai kelas eksperimen.

Tabel1. Desain Penelitian

\begin{tabular}{|c|c|c|c|}
\hline Kelompok & $\begin{array}{c}\text { Kemampuan } \\
\text { Awal }\end{array}$ & Perlakuan & $\begin{array}{c}\text { Kemampuan } \\
\text { Akhir }\end{array}$ \\
\hline Eksperimen & $\mathrm{O}_{1}$ & $\mathrm{X}$ & $\mathrm{O}_{2}$ \\
\hline
\end{tabular}

Keterangan:

$\mathrm{O}_{1} \quad$ : Pre-test (tes awal sebelum proses belajar mengajar dimulai dan belum diberikan perlakuan)

$\mathrm{O}_{2} \quad$ : Post-test (tes akhir setelah proses belajar mengajar berlangsung dan diberikan perlakuan)

$\mathrm{X} \quad$ : Perlakuan (Treatment) melaksanakan pembelajaran menggunakan model pembelajaran STAD

Teknik pengumpulan data yang digunakan adalah tes kemampuan pemahaman matematis dan angket untuk mendapatkan keterangan dari sampel atau sumber yang beraneka ragam yang berada dilokasi penelitian. Penelitian dalam teknik ini akan memberikan angket kepada setiap siswa yang dijadikan sampel penelitian. Dengan metode ini dimaksudkan untuk memperoleh data yang berkaitan dengan kemampuan pemahaman konsep siswa pada kelas X SMA Negeri 2 Torgamba.

Sebelum tes kemampuan pemahaman matematika digunakan, dilakukan uji coba terlebih dahulu dengan tujuan untuk mengetahui apakah soal tersebut sudah memenuhi persyaratan validitasi, reabilitasi, tingkat kesukaran dan daya beda.

1. Validitas

Cara mencari koefisien validitas yang digunakan dalam penelitian ini adalah dengan menggunakan rumus korelasi produk moment memakai angka kasar (raw score) yaitu[8]:

$$
r_{x y}=\frac{N \sum X Y-\left(\sum X\right)\left(\sum Y\right)}{\sqrt{\left\{N \sum X^{2}-\left(\sum X\right)^{2}\right\}\left\{N \sum Y^{2}-\left(\sum Y\right)^{2}\right\}}}
$$

Diketahui $r_{X Y}=$ Koefisien korelasi antara variabel $\mathrm{X}$ dan variabel $\mathrm{Y}$

$$
\begin{array}{ll}
X & =\text { Nilai hasil uji coba tiap item } \\
Y & =\text { Nilai total siswa } \\
N & =\text { Banyak peserta tes uji coba }
\end{array}
$$

Selanjutnya dihitung dengan Uji-t dengan rumus :

$$
\mathrm{T}_{\text {hitung }}=\frac{r \sqrt{n-2}}{\sqrt{1-r^{2}}}
$$

Distribusi (tabel $\mathrm{t}$ ) untuk $\propto=0,05$ dan derajat kebebasan ( $\mathrm{dk}=\mathrm{n}-2)$.

Kaidah keputusan :

Jika $t_{\text {hitung }} \geq t_{\text {tabel }}$ berarti valid, sebaliknya

Jika $t_{\text {hitung }}<t_{\text {tabel }}$ berarti tidak valid

Jika instrumen itu valid, maka kriteria yang digunakan untuk menentukan validitas butir soal adalah :
$0,80<r \leq 1,00$
$0,60<r \leq 0,79$
$0,40<r \leq 0,59$
Sangat Tinggi
Tinggi
Cukup
$0,20<r \leq 0,39$
Rendah
$0,00<r \leq 0,19$
Sangat Rendah

2. Reliabilitas

Rumus yang digunakan untuk mencari koefisien reliabilitas bentuk uraian dikenal dengan rumus Cronbach Alpha seperti berikut[9]:

$$
r_{p}=\frac{b}{b-1} \times \frac{D B_{j}^{2}-\sum D B_{i}^{2}}{D B_{j}^{2}}
$$

Dimana :

b : adalah banyaknya soal 
Hal : 20-25

$D B_{j}^{2} \quad$ : adalah variansi skor seluruh soal menurut skor perorangan

$D B_{i}^{2} \quad$ : adalah variansi skor soal tertentu (soal ke-i)

$\sum D B_{i}^{2}$ : adalah jumlah variansi skor seluruh soal menurut skor soal tertentu

Kriteria reliabilitas yang dibuat oleh Guilford dikategorikan sebagai berikut[9]:

$0,00<\mathrm{r}_{p} \leq 0,20$ derajat reliabilitas sangat rendah

$0,20<r_{p} \leq 0,40$ derajat reliabilitas rendah

$0,40<r_{p} \leq 0,60$ derajat reliabilitas sedang

$0,60<r_{p} \leq 0,80$ derajat reliabilitas tinggi

$0,80<r_{p} \leq 1,00$ derajat reliabilitas sangat Tinggi

\section{Hasil dan Pembahasan}

Uji yang digunakan untuk menganalisis data tes kemampuan siswa adalah uji perbedaan dua rata-rata. Uji perbedaan dua rata-rata yang akan digunakan adalah uji $t$, akan tetapi uji $t$ dapat digunakan apabila memenuhi persyaratan yaitu:

1. Sampel berasal dari data yang berdistribusi normal. Hal ini dapat diketahui dengan melakukan uji normalitas.

2. Varians kedua populasi homogen. Hal ini dapat diketahui dengan melakukan uji homogenitas.

a. Uji Normalitas

Berdasarkan data yang diperoleh dari nilai pretest dan posttest, maka diperoleh hasil uji normalitas seperti tabel dibawah ini:

Tabel 2. Rekapitulasi Hasil Perhitungan Uji Normalitas dikelas Eksperimen

\begin{tabular}{|c|c|c|c|c|}
\hline Data & Kelas & $\mathrm{X}_{\text {hitung }}$ & $\mathrm{X}_{\text {tabel }}$ & Kesimpulan \\
\hline Pretest & $\mathrm{X}-2$ & 36.05 & 54.57 & $\begin{array}{c}\text { Ho diterima } \\
\text { (normal) }\end{array}$ \\
\hline Posttest & $\mathrm{X}-2$ & 38.05 & 54.57 & $\begin{array}{c}\text { Ho diterima } \\
\text { (normal) }\end{array}$ \\
\hline
\end{tabular}

Berdasarkan tabel 2 diatas menunjukkan bahwa data nilai pretest dan posttest kemampuan pemahaman konsep matematika siswa yang menggunakan model STAD di kelas eksperimen berdistribusi normal. Hal ini ditunjukkan dari nilai $t_{\text {hitung }}$ yaitu 36,05 dan 38,05 lebih kecil dari nilai $t_{\text {tabel }}$ yaitu 54,57 . Artinya $\mathrm{X}^{2}{ }_{\text {hitung }} \leq \mathrm{X}^{2}$ tabel, maka $\mathrm{H}_{\mathrm{o}}$ diterima.

b. Uji Homogenitas

Setelah data pretest dan posttest berdistribusi normal, langkah selanjutnya data memiliki varians yang sama atau tidak. Hasil data dapat dilihat seperti tabel dibawah ini:

Tabel 3. Rekapitulasi Hasil Perhitungan Uji Homogenitas

\begin{tabular}{|c|c|c|c|c|c|}
\hline Data & Kelas & $\mathrm{N}$ & $\mathrm{F}_{\text {hitung }}$ & $\mathrm{F}_{\text {tabel }}$ & Kesimpulan \\
\hline Pretest dan Possttest & $\mathrm{X}-2$ & 40 & 1,13 & 2,02 & Homogen \\
\hline
\end{tabular}

Berdasarkan tabel 3 diatas diketahui bahwa nilai $F_{\text {hitung }}$ sebesar 1,13 dan $F_{\text {tabel }}$ sebesar 2,02, maka dapat disimpulkan bahwa $\mathrm{H}_{\mathrm{o}}$ diterima. Artinya bahwa data pre-test dan post-test kelas eksperimen homogen.

c. Uji Hipotesis

Untuk uji hipotesis manual dilakukan dengan menggunakan uji t dengan pengambilan keputusan jika $t_{\text {itung }}>t_{\text {tabel }}$ maka Ho ditolak.

Tabel 4. Rekapitulasi Hasil Perhitungan Uji t di Kelas Eksperimen

\begin{tabular}{|c|c|c|c|c|}
\hline Data & Kelas & $\mathrm{N}$ & $\mathrm{t}_{\text {hitung }}$ & Kesimpulan \\
\hline Pretest dan posttest & $\mathrm{X}-2$ & 42 & 13,250 & $\mathrm{H}_{0}$ Hoditolak \\
& & 40 & 13 diterima \\
\hline
\end{tabular}


Berdasarkan tabel 4 hasil perhitungan uji t yang ditunjukkan pada tabel diatas dengan taraf signifikan $\alpha=0,05 / 2$ $=0,025$ (dua sisi). Kemudian dicari $t_{\text {tabel }}$ pada tabel distribusi t dengan ketentuan $\mathrm{db}=\mathrm{n}-1, \mathrm{db}=40-1=39$ dalam kasus ini $t_{\text {tabel }}$ yang dimaksud adalah 2,02. Dan nilai $t_{\text {hitung }}$ sebesar $13,250>t_{\text {tabel }}$ yaitu 2,02 yang berarti terdapat pengaruh kemampuan pemahaman konsep matematika dengan model STAD dikelas eksperimen yang signifikan antara pre-test maupun post-test.

\section{d. Analisis Hasil terhadap Angket Respon Siswa}

Angket digunakan untuk mengetahui respon siswa terhadap pembelajaran dengan menggunakan metode Student Teams Achievement Divisions (STAD). angket respon siswa ini diberikan kepada siswa dikelas eksperiment pada pertemuan terakhir dan diisi oleh 40 siswa. Untuk memudahkan pembahasan, analisis angket dibagi kedalam dua bagian yaitu variable $X$ ( model pembelajaran STAD) dan variable $Y$ (model STAD terhadap materi SPLDV). Adapun hasil dari respon siswa adalah sebagai berikut:

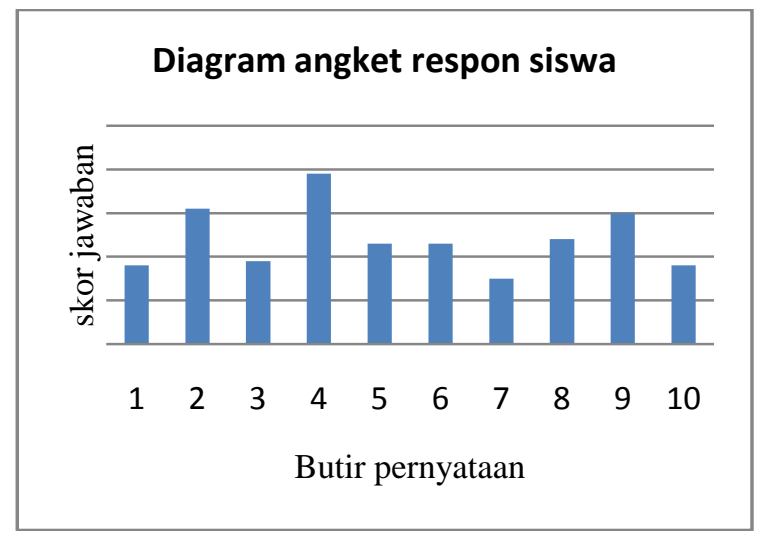

Gambar 1. Rekapitulasi Diagram Angket Respon Siswa

Berdasarkan hasil pengolahan angket bahwa respon siswa terhadap butir pernyataan pertama sebanyak 28 orang $(79 \%)$ setuju, butir pernyataan kedua sebanyak 35 siswa $(85,5 \%)$ sangat setuju, butir pernyataan ketiga sebanyak 29 siswa (79,5\%) setuju, butir pernyataan ke-4 sebanyak 30 siswa $(89,5 \%)$ sangat setuju. Butir pernytaan ke-5 sebanyak 32 siswa $(81,5 \%)$ sangat setuju, butir pernyataan ke-6 sebanyak 31 siswa $(81,5 \%)$ sangat setuju, butir pernyataan ke-7 sebanyak 29 siswa $(77,5 \%)$ setuju, butir pernyataan ke-8 sebanyak 29 siswa $(82 \%)$ sangat setuju, butir pernyataan ke-9 sebanyak 33 siswa $(85 \%)$ sangat setuju, dan butir pernyataan ke-10 sebanyak 29 siswa (79\%) setuju.

Berdasarkan hasil pengolahan angket diperoleh bahwa respon siswa terhadap model pembelajaran Student Teams Achievement Divisions pada materi sistem persamaaan linear dua variabel sebesar $82(41 \%)$. Hal ini menunjukkan respon siswa terhadap model pembelajaran Student Teams Achievement Divisions (STAD) pada materi sistem persamaaan linear dua variabel sangat disetujui siswa.

\section{Pembahasan}

Berdasarkan hasil pengolahan data yang telah diuraikan sebelumnya, skor sebelum diberi perlakuan dan skor setelah diberi perlakuan terdapat perbedaan. Hal ini terlihat dari hasil pengujian hipotesis dengan uji Paired Samples $T$-Test diperoleh nilai $t_{\text {tabel }}=2,02<t_{\text {itung }}=13,250$. maka $\mathrm{H}_{0}$ ditolak dan $\mathrm{H}_{\mathrm{a}}$ diterima dengan kata lain terdapat pengaruh Model Pembelajaran Student Teams Achievement Divisions (STAD) Terhadap Kemampuan Pemahaman konsep matematika siswa pada materi Sistem Persamaan Linear Dua Variabel (SPLDV).

Berdasarkan pengamatan pada saat meneliti dikelas $\mathrm{X}^{2}$, proses tersebut dapat dilihat bahwa siswa dituntut untuk mampu menyelesaikan soal cerita, menggambar grafik tujuan ini adalah untuk mengetahui kemampuan pemahaman konsep siswa. Pembelajaran dengan model Student Teams Achievement Divisions (STAD) memperkenalkan konsep matematika kepada siswa, siswa pada akhirnya dapat menemukan konsep, dengan bantuan guru atau teman. Siswa dibagi dalam beberapa kelompok dan aktivitas pembelajaran dikelas terjadi saling interaksi didalam kelompok masing-masing, kemudian siswa diarahkan untuk mendiskusikan penyelesaian terhadap masalah yang mereka temukan (biasanya ada yang berbeda pendapat, baik cara menemukannya maupun hasilnya).

Selain dilihat dari uji hipotesis, pengaruh kemampuan pemahaman konsep matematika siswa juga dapat dilihat dari skor terendah siswa saat pretest adalah 19, setelah diberi perlakuan skor posttest terendah menjadi 
21. Skor tertinggi pretest siswa adalah 47, setelah diberi perlakuan skor posttest tertinggi adalah 48 . Maka disimpulkan bahwa setelah diberi perlakuan terdapat peningkatan atau dengan kata lain skor posttest lebih tinggi dibandingkan skor pretest. Berarti Model Pembelajaran Student Teams Achievement Divisions (STAD) mempengaruhi kemampuan pemahaman konsep matematis siswa. Dengan demikian penelitian "Pengaruh Model Pembelajaran Student Teams Achievement Divisions (STAD) mempengaruhi kemampuan pemahaman konsep matematika siswa pada materi Sistem Persamaan Linear Dua Variabel (SPLDV)" mampu menjawab hipotesis yang diajukan melalui analisis data-data yang diperoleh yaitu penelitian membuktikan bahwa terdapat pengaruh Model Pembelajaran Student Teams Achievement Divisions (STAD) mempengaruhi kemampuan penalaran matematis siswa.

Berdasarkan hasil pengolahan angket diperoleh bahwa respon siswa terhadap model pembelajaran Student Teams Achievement Divisions pada materi sistem persamaaan linear dua variabel sebesar 82 (41\%). Hal ini menunjukkan respon siswa terhadap model pembelajaran Student Teams Achievement Divisions pada materi sistem persamaaan linear dua variabel sangat disetujui siswa.

\section{Kesimpulan}

Terdapat pengaruh model pembelajaran Student Teams Achievement Divisions terhadap kemampuan pemahaman konsep siswa kelas X SMA Negeri 2 Torgamba, dapat dilihat dari nilai signifikan antara pre-test maupun post-test. Dari hasil tes tersebut terlihat peningkatan antara nilai pretest dengan nilai posttest yaitu nilai rata-rata pretest sebesar 35,125 dan nilai rata-rata posttest sebesar 37,075. Untuk pengujian hipotesis menggunakan uji-t dengan teknik paired samples $t$-test dengan hasil $t_{\text {hitung }}$ sebesar 13,250 dan nilai $t_{\text {tabel }}$ sebesar 2,02 dengan taraf signifikan 0,05 dengan $\mathrm{dk}=40$. Berdasarkan hasil pengolahan angket diperoleh bahwa respon siswa terhadap model pembelajaran Student Teams Achievement Divisions (STAD) pada materi sistem persamaaan linear dua variabel sebesar 82 (41\%). Hal ini menunjukkan respon siswa terhadap model pembelajaran Student Teams Achievement Divisions (STAD) pada materi sistem persamaaan linear dua variabel sangat disetujui siswa.

\section{Daftar Pustaka}

[1] Erlanda, Rici. 2014. Pengaruh Model Pemebelajaran Collaborative MURDER terhadap Pemahaman Konsep Matematika Siswa, Universitas Islam Negeri Syarif Hidayatullah, Jakarta.

[2] Uno, Hamzah B. 2006. Perencanaan Pembelajaran Bumi Aksara. Jakarta

[3] Siregar, S.U. (2016). Perbedaan Kemampuan Pemecahan Masalah Matematika Menurut Teori Belajar Bruner dan Teori Belajar Vigosky pada Kompetensi Dasar Menghitung Luas dan Keliling Bangun Datar kelas V Semester 2 SD Negeri 114375 Binaraga Rantauprapat. Jurnal Pembelajaran dan Matematika Sigma (JPMS). Vol. 2 No.2, hlm. 51-53. 2016

[4] Hrp, N.A., Rahma, I.F. 2020. Keefektifan Penerapan Model Pembelajaran Berbasis Proyek Dalam Pencapaian Aspek Kemampuan Representasi dan Komunikasi Matematis Siswa Kelas VI SD Negeri 118296 Beringin Jaya Pinang Damai. Jurnal Pendidikan Matematika (Phi). Vol. 4 No. 2 Tahun 2020

[5] Harahap, H.S, Hrp, N.A, Nasution, I.B, Harahap, A, Harahap, A, Harahap, A. 2021. Hubungan Motivasi Berprestasi, Minat dan Perhatian Orang Tua Terhadap Kemandirian Siswa. Edukatif : Jurnal IImu Pendidikan Volume 3 Nomor 4 Tahun 2021 Halm 1133 - 1143

[6] Suryani. 2019. Pengaruh Model Pembelajaran Student Teams Achievement Division (STAD) terhadap Kemampuan Pemecahan Masalah Matematika. Jurnal Pembelajaran dan Matematika Sigma (JPMS). Vol. 5, No. 1 (2019) hal.1-6

[7] Siwa, L.A.R, Safitri, I, Pasaribu, L.H. 2018. Perbandingan Model Pembelajaran Kooperatif Tipe Jigsaw dengan STAD (Student Team Achiement Division) Terhadap Kemampuan Pemecahan Masalah Matematika Siswa Kelas XI SMA Muhammadiyah 10 Rantauprapat. Jurnal Pembelajaran dan Matematika Sigma (JPMS). Vol. 4, No. 2 (2018) hal.17-26

[8] Arikunto, S. 2003. Prosedur Penelitian Suatu Pendekatan Praktek. Jakarta. Rineka Cipta.

[9] Suherman, Erman dkk. 2003. Strategi Pembelajaran Matematika Kontemporer. Bandung: PT Remaja Rosdakarya. 

Jurnal Pembelajaran dan Matematika Sigma (JPMS)

ISSN : 2460-593X

Vol. 7, No. 1 (2021)

E-ISSN : 2685- 5585

Hal : 20-25 